\title{
Pengaruh Pengetahuan dan Perilaku Kesehatan Gigi dan Mulut terhadap Persepsi Permasalahan Gingiva Lansia di Unit Rehabilitasi Sosial Pucang Gading Kota Semarang
}

\author{
Milenda E. K. Asri, ${ }^{1}$ Astika W. Utomo, ${ }^{2}$ Ira A. Kusuma, ${ }^{1}$ Isniya Nosartika ${ }^{1}$
}

\author{
${ }^{1}$ Program Studi Kedokteran Gigi Fakultas Kedokteran Universitas Diponegoro, Semarang, \\ Indonesia \\ ${ }^{2}$ Departemen Kedokteran Universitas Diponegoro, Semarang, Indonesia \\ Email: dent_niya@yahoo.com \\ Disubmisi: 1 Juli 2021; direvisi: 9 Agustus 2021; diterima: 13 Agustus 2021
}

\begin{abstract}
Decrease of physical and cognitive conditions in the elderly makes them become risky for periodontal disease. Lack of knowledge and poor behavior of oral health are the main causes of periodontal disease. Gingival health problems can be detected in the elderly by observing the signs and symptoms of gingivitis. This study was aimed to analyze the influence of knowledge and behaviour of oral health on perception of gingival health problems in the elderly living at Unit Rehabilitasi Sosial (nursery home) Pucang Gading Semarang. This was an observational and analytical study with a cross-sectional design. Samples were 74 elderlies at Unit Rehabilitasi Sosial Pucang Gading Semarang, obtained by using the purposive sampling method. Data were collected by using questionnaire and were analyzed by using the Gamma and Somers'd test followed by multinomial logistic regression test. The results showed that most of the elderly at Pucang Gading Social Rehabilitation Unit had poor oral health knowledge and oral health behavior. Most elderlies had moderate perception of gingival problems. Multinomial logistic regression about the influence of knowledge and behaviour of oral health on perception of gingival health resulted in a p-value of $0.000(\mathrm{p}<0.05)$. In conclusion, there was a significant influence of knowledge and behavior of oral health on the perception of gingival problems in the elderly.
\end{abstract}

Keywords: oral health knowledge; oral health behaviour; perception of gingival problem; elderly

\begin{abstract}
Abstrak: Penurunan kondisi fisik dan kognitif pada lanjut usia (lansia) menyebabkan mereka lebih berisiko terkena penyakit periodontal. Kurangnya pengetahuan dan perilaku kesehatan gigi dan mulut merupakan salah satu penyebab utama terjadinya penyakit jaringan periodontal. Permasalahan kesehatan gingiva dapat dideteksi pada lansia dengan mengetahui tanda dan gejala gingivitis. Penelitian ini bertujuan untuk mengetahui pengaruh pengetahuan dan perilaku kesehatan gigi dan mulut terhadap persepsi permasalahan gingiva lansia di Unit Rehabilitasi Sosial Pucang Gading Kota Semarang. Jenis penelitian ialah observasional analitik dengan desain potong lintang. Responden penelitian ini ialah 74 lansia yang tinggal di Unit Rehabilitasi Sosial Pucang Gading Kota Semarang yang memenuhi kriteria inklusi dan eksklusi diperoleh dengan metode purposive sampling. Pengambilan data dilakukan menggunakan kuesioner. Data dianalisis menggunakan uji Gamma \& Somers'd dilanjutkan dengan uji regresi logistik multinomial. Hasil penelitian memperlihatkan bahwa lansia paling banyak memiliki pengetahuan dan perilaku kesehatan gigi dan mulut yang buruk serta persepsi permasalahan gingiva sedang. Hasil analisis uji regresi logistik multinomial mengenai pengaruh pengetahuan dan perilaku kesehatan gigi dan mulut terhadap persepsi permasalahan gingiva mendapatkan nilai $p=0,000(p<0,05)$. Simpulan penelitian ini ialah terdapat pengaruh bermakna dari pengetahuan dan perilaku kesehatan gigi dan mulut terhadap persepsi permasalahan gingiva pada lanjut usia.
\end{abstract}

Kata kunci: pengetahuan kesehatan gigi dan mulut; perilaku kesehatan gigi dan mulut; persepsi permasalahan gingiva; lanjut usia (lansia) 


\section{PENDAHULUAN}

Lanjut usia (lansia) atau menua ialah tahapan terakhir dari siklus kehidupan individu. ${ }^{1}$ Lansia adalah individu yang usianya mencapai 60 tahun atau lebih, baik yang aktif berkegiatan secara fisik maupun yang tidak. $^{2}$

Menurut jumlah perkiraan penduduk pada profil lansia kota semarang tahun 2018, jumlah lansia meningkat menjadi 156,9 ribu jiwa atau sebesar $8,78 \%$. Berdasarkan profil lansia Kota Semarang tahun 2018, separuh lansia di Kota Semarang mengalami keluhan kesehatan, antara lain demam, batuk, sesak nafas, asma, pilek, sakit perut, sakit kepala berulang, diare, penyakit gigi dan mulut, dan lain-lain. ${ }^{3,4}$

Salah satu keluhan kesehatan yang banyak dikeluhkan penduduk lansia di Kota Semarang dan termasuk pola 10 besar penyakit puskesmas ialah penyakit pulpa dan jaringan penyangga (jaringan periodontal). ${ }^{5}$ Lansia mengalami penurunan kondisi fisik dan kognitif akibat proses menua yang menyebabkan lansia lebih berisiko terkena penyakit jaringan periodontal. ${ }^{6,7}$ Salah satu faktor yang dapat memengaruhi penurunan fungsi kognitif yaitu kurangnya dukungan dari keluarga. ${ }^{8}$

Lansia yang tinggal di panti jompo hidup jauh dari keluarga, kurang kasih sayang, kurang beraktifitas serta memiliki keterbatasan ekonomi sehingga cenderung kurang memperhatikan kesehatannya. ${ }^{8}$ Dinas Sosial Kota Semarang menetapkan Unit Rehabilitasi Sosial Pucang Gading Kota Semarang sebagai tempat dalam pelaksanaan pelayanan lansia terlantar. ${ }^{9}$ Tingkat ekonomi yang rendah memengaruhi tingkat pendidikan, faktor pekerjaan, serta pengalaman dan pelayanan kesehatan yang merupakan faktor yang memengaruhi pengetahuan dan perilaku kesehatan gigi dan mulut.

Pengetahuan merupakan domain kognitif yang sangat penting dalam pembentukan perilaku. ${ }^{10}$ Kurangnya pengetahuan mengenai kesehatan gigi dan mulut merupakan faktor predisposisi dari perilaku kesehatan yang mengarah kepada terjadinya penyakit. ${ }^{11}$ Perilaku merupakan respon evaluatif, yang terjadi ketika seseorang berhadapan dengan situasi yang menghendaki adanya reaksi. Perilaku merupakan suatu pengetahuan, namun diikuti oleh tendensi untuk melakukan suatu tindakan sesuai dengan pengetahuan itu. ${ }^{12}$

Pengetahuan dan perilaku kesehatan gigi dan mulut yang buruk adalah salah satu penyebab utama terjadinya penyakit pada jaringan periodontal. Salah satu penyakit jaringan periodontal yang paling sering terjadi ialah gingivitis. ${ }^{13}$ Di Indonesia, masalah pada gingiva menduduki urutan kedua masalah kesehatan gigi dan mulut, yakni mencapai 96,58\%. ${ }^{14}$ Gingivitis adalah penyakit pada jaringan periodontal yang mengenai jaringan gingiva karena invasi bakteri dan mempunyai sifat reversibel apabila plak gigi dibersihkan dan menyikat gigi secara teratur. Gingivitis yang tidak terawat dapat berlanjut ke periodontitis. ${ }^{13}$ Permasalahan kesehatan gingiva dapat dideteksi pada lansia dengan mengetahui persepsi lansia terhadap tanda dan gejala gingivitis.

Persepsi merupakan kumpulan penginderaan untuk mengenali suatu benda atau hal sebagai bentuk aktivitas kognitif dimana otak aktif menyatukan berbagai memori dan juga ingatan dari peristiwa yang sudah dialami sebelumnya untuk memberikan penilaian baik atau buruk. ${ }^{15}$ Persepsi permasalahan kesehatan gingiva meliputi penilaian individu terhadap kondisi gingiva seperti mudah berdarah, berwarna merah, terjadi pembesaran, dan lainnya

Melihat tingginya prevalensi penyakit jaringan periodontal pada lansia di Kota Semarang, penulis ingin mengkaji lebih lanjut mengenai pengaruh pengetahuan dan perilaku kesehatan gigi dan mulut terhadap persepsi permasalahan gingiva lansia di Unit Rehabilitasi Sosial Pucang Gading Kota Semarang. Selain itu, penelitian demikian belum pernah dilakukan sebelumnya pada lansia di Unit Rehabilitasi Sosial Pucang Gading Kota Semarang.

\section{METODE PENELITIAN}

Jenis penelitian ini ialah analitik observasional dengan desain potong lintang. Sampel penelitian ini ialah lansia yang 
tinggal di Unit Rehabilitasi Sosial Pucang Gading Kota Semarang. Responden yang termasuk dalam penelitian berusia lebih dari 60 tahun, bersedia menjadi responden dan mengisi informed consent, bisa membaca dan menulis, serta kooperatif dalam menjawab pertanyaan kuesioner. Kriteria eksklusi ialah lansia yang menderita penyakit yang menyebabkan lansia tidak mampu melakukan higieni mulut secara mandiri dan tidak kooperatif dalam berkomunikasi.

Kuesioner yang digunakan dalam penelitian ini terdiri dari kuesioner pengetahuan dan perilaku kesehatan gigi dan mulut serta kuesioner persepsi permasalahan gingiva. Kuesioner pengetahuan kesehatan gigi dan mulut terdiri dari 14 pernyataan mengenai pengetahuan kesehatan gigi dan mulut dengan pilihan benar (1) dan salah (0). Kuesioner perilaku kesehatan gigi dan mulut terdiri dari 17 pernyataan mengenai perilaku kesehatan gigi dan mulut dengan pilihan jawaban tidak pernah (0), jarang (1), kadang-kadang (2), sering (3), selalu (4). Kuesioner persepsi permasalahan gingiva terdiri dari empat pertanyaan mengenai permasalahan gingiva dengan pilihan jawaban ya (1) dan tidak (0).

Pada penelitian ini terdapat 75 responden yang diperoleh dengan metode purposive sampling. Pengisian kuesioner dan informed consent dilakukan secara langsung dengan atau tanpa bantuan pengurus panti. Data yang diperoleh meliputi nama, usia, tingkat pengetahuan kesehatan gigi dan mulut, perilaku kesehatan gigi dan mulut serta persepsi permasalahan gingiva. Data kuesioner yang terkumpul diolah dan dianalisis menggunakan aplikasi SPSS. Analisis data dilakukan menggunakan uji Gamma \& Somers'd dan dilanjutkan dengan uji regresi logistik multinomial dengan nilai signifikansi $p<0,05$.

Penelitian ini telah mendapat persetujuan dari Komisi Etik Penelitian Kesehatan Fakultas Kedokteran Universitas Diponegoro, Semarang, dengan Nomor 25/EC/ KEPK/FK-UNDIP/II/2021.

\section{HASIL PENELITIAN}

Tabel 1 memperlihatkan distribusi karakteristik responden berasarkan jenis kela- min dan usia. Sampel akhir yang diperoleh sebanyak 74 responden dengan 1 data drop out. Responden terbanyak berjenis kelamin perempuan serta berusia 60-74 tahun.

Tabel 1. Distribusi karakteristik responden berdasarkan usia dan jenis kelamin

\begin{tabular}{ccc}
\hline Variabel & F & \% \\
\hline Jenis kelamin & & \\
Laki-laki & 27 & 36,5 \\
Perempuan & 47 & 63,5 \\
Usia & & \\
60-74 tahun & 43 & 58,1 \\
75-90 tahun & 30 & 40,5 \\
$>90$ tahun & 1 & 1,4 \\
\hline
\end{tabular}

Tabel 2 memperlihatkan permasalahan gingiva pada responden. Sebagian besar responden mengalami permasalahan gusi bengkak yaitu sebanyak 39 orang $(52,0 \%)$, dan paling sedikit yang mengalami permasalahan pertumbuhan berlebih pada gusi yaitu sebanyak 32 orang $(42,7 \%)$.

Tabel 2. Permasalahan gingiva pada lansia di Unit Rehabilitasi Sosial Pucang Gading Kota Semarang

\begin{tabular}{lcc}
\hline Permasalahan gingiva & n & f \\
\hline Gusi mudah berdarah & 36 & $48,63 \%$ \\
Gusi bengkak & 39 & $52,7 \%$ \\
$\begin{array}{l}\text { Gusi berwarna merah } \\
\text { terang/kebiruan }\end{array}$ & 36 & $48,6 \%$ \\
$\begin{array}{l}\text { Pertumbuhan berlebih } \\
\text { pada gusi }\end{array}$ & 32 & $43,2 \%$ \\
\hline
\end{tabular}

Tabel 3 memperlihatkan hasil analisis hubungan pengetahuan dan perilaku kesehatan gigi dan mulut. Hasil uji mendapatkan nilai $p=0,355(p>0,05)$ yang menunjukkan tidak terdapat hubungan bermakna antara pengetahuan dengan perilaku kesehahan gigi dan mulut.

Tabel 4 memperlihatkan hasil analisis uji Gamma dan Somers'd mengenai pengaruh pengetahuan kesehatan gigi dan mulut terhadap persepsi permasalahan gingiva dengan nilai $p=0,001(p<0,05)$ yang menunjukkan terdapat pengaruh bermakna pengetahuan kesehatan gigi dan mulut terhadap 
persepsi permasalahan gingiva.

Tabel 5 memperlihatkan hasil analisis uji Gamma dan Somers'd mengenai pengaruh perilaku kesehatan gigi dan mulut terhadap persepsi permasalahan gingiva dengan nilai $\mathrm{p}=0,002(\mathrm{p}<0,05)$ yang menunjukkan terdapat pengaruh bermakna perilaku kesehatan gigi dan mulut terdahap persepsi permasalahan gingiva.

Hasil analisis uji regresi logistik multinomial mengenai pengaruh pengetahuan dan perilaku kesehatan gigi dan mulut terhadap persepsi permasalahan gingiva mendapatkan nilai $\mathrm{p}=0,000(\mathrm{p}<0,05)$ yang menunjukkan bahwa pengetahuan dan perilaku kesehatan gigi berpengaruh simul- tan terhadap persepsi permasalahan gingiva.

\section{BAHASAN}

Hasil penelitian memperlihatkan bahwa lansia yang tinggal di Unit Rehabilitasi Sosial Pucang Gading Kota Semarang terbanyak memiliki tingkat pengetahuan kesehatan gigi dan mulut "buruk". Menurut Notoatmodjo, ${ }^{16}$ pengetahuan dipengaruhi oleh faktor pendidikan, pekerjaan, pengalaman, keyakinan, dan sosial budaya. Lansia dalam penelitian ini merupakan lansia terlantar yang memiliki tingkat sosial ekonomi rendah sehingga cenderung memiliki tingkat pengetahuan kesehatan gigi dan mulut yang buruk. ${ }^{17}$

Tabel 3. Hasil analisis uji chi square mengenai hubungan pengetahuan dengan perilaku kesehatan gigi dan mulut

\begin{tabular}{lccccc}
\hline $\begin{array}{l}\text { Tingkat } \\
\text { pengetahuan } \\
\text { kesehatan gigi } \\
\text { dan mulut }\end{array}$ & Baik & Sedang & Buruk & Total & Nilai p \\
\hline Baik & & & & & \\
Cukup & $8(10,8 \%)$ & $15(20,3 \%)$ & $8(10,8 \%)$ & $31(41,9 \%)$ & \\
Buruk & $1(1,4 \%)$ & $4(5,4 \%)$ & $5(6,7 \%)$ & $10(13,5 \%)$ & \\
Total & $6(8,1 \%)$ & $11(14,9 \%)$ & $16(21,6 \%)$ & $33(44,6 \%)$ & 0.355 \\
\hline
\end{tabular}

Tabel 4. Hasil analisis uji Gamma dan Somers'd mengenai pengaruh pengetahuan kesehatan gigi dan mulut terhadap persepsi permasalahan gingiva

\begin{tabular}{lccccc}
\hline $\begin{array}{l}\text { Persepsi } \\
\text { permasalahan } \\
\text { gingiva }\end{array}$ & \multicolumn{2}{c}{ Tingkat pengetahuan kesehatan gigi dan mulut } & Total & Nilai p \\
\hline Baik & Baik & Cukup & Buruk & & \\
Sedang & $18(24,3 \%)$ & $1(1,4 \%)$ & $9(12,1 \%)$ & $28(37,8 \%)$ & \\
Buruk & $10(13,5 \%)$ & $9(12,1 \%)$ & $15(20,4 \%)$ & $34(46,0 \%)$ & 0,001 \\
Total & $3(4,1 \%)$ & $0(0 \%)$ & $9(12,1 \%)$ & $12(16,2 \%)$ & \\
\hline
\end{tabular}

Tabel 5. Hasil analisis uji Gamma dan Somers'd mengenai pengaruh perilaku kesehatan gigi dan mulut terhadap persepsi permasalahan gingiva

\begin{tabular}{lccccc}
\hline $\begin{array}{l}\text { Persepsi } \\
\text { permasalahan } \\
\text { gingiva }\end{array}$ & \multicolumn{2}{l}{ Perilaku kesehatan gigi dan mulut } & \multirow{2}{*}{ Total } & \multirow{2}{*}{ Nilai p } \\
\hline Baik & $12(16,2 \%)$ & $8(10,8 \%)$ & $8(10,8 \%)$ & $28(37,8 \%)$ & \\
Sedang & $1(1,4 \%)$ & $17(23 \%)$ & $16(21,6 \%)$ & $34(46 \%)$ & \multirow{2}{*}{ Sedang } \\
Buruk & $2(2,6 \%)$ & $5(6,8 \%)$ & $5(6,8 \%)$ & $12(16,2 \%)$ & \multirow{2}{*}{ Buruk } \\
Total & $15(20,2 \%)$ & $30(40,6 \%)$ & $29(39,2 \%)$ & $74(100 \%)$ & \\
\hline
\end{tabular}


Hasil penelitian memperlihatkan bahwa lansia yang berusia 60-74 tahun cenderung memiliki tingkat pengetahuan kesehatan gigi dan mulut yang lebih baik dibanding dengan lansia yang berusia 75-90 tahun. Dengan bertambahnya usia, seseorang akan mengalami perubahan pada aspek fisik dan psikologis (mental). ${ }^{18}$ Penurunan kualitas fisik secara drastis dapat berpengaruh terhadap kondisi psikologis maupun sosial dan menyebabkan kebiasaan bergantung dengan orang lain. Berubahnya kedua aspek tersebut akan berdampak pada perubahan aspek psikososial dan ekonomi lansia. ${ }^{19}$

Hasil penelitian memperlihatkan bahwa terbanyak lansia memiliki perilaku kesehatan gigi dan mulut "sedang" dan "buruk" yaitu masing-masing berjumlah 30 responden $(40 \%)$. Perilaku kesehatan gigi dan mulut dipengaruhi beberapa faktor, salah satunya faktor materi misalnya ketersediaan fasilitas dan sarana. ${ }^{20}$ Lansia yang tinggal di Unit Rehabilitasi Sosial Pucang Gading Kota Semarang cenderung kurang mendapatkan fasilitas dan sarana kesehatan gigi dan mulut yang memadai. Purnamasari ${ }^{17}$ melaporkan bahwa Unit Rehabilitasi Sosial Pucang Gading Kota Semarang memiliki pelayanan kesehatan yaitu kunjungan dokter umum dan psikiatri rutin namun belum tersedia pelayanan kesehatan gigi dan mulut; hal ini dapat menjadi salah satu faktor yang memengaruhi masih kurangnya kesadaran lansia yang tinggal di Unit Rehabilitasi Sosial Pucang Gading Kota Semarang dalam menjaga kesehatan gigi dan mulut.

Lansia pada penelitian ini paling banyak memiliki persepsi permasalahan gingiva "sedang" yaitu sebanyak 34 orang $(45,3 \%)$. Berdasarkan jenis kelamin, persepsi permasalahan gingiva lansia wanita lebih baik daripada lansia pria. Hal ini sejalan dengan penelitian oleh Hutauruk ${ }^{21}$ (2017), yang mendapatkan poket dangkal dan poket dalam memiliki frekuensi yang lebih tinggi pada lansia pria, Adanya perbedaan persepsi permasalahan gingiva antara pria dan wanita disebabkan pria lebih banyak memiliki kebiasaan buruk seperti konsumsi alkohol dan merokok. Penelitian oleh Chatzopoulos et $\mathrm{al}^{22}$ mendapatkan $31,7 \%$ subjek penelitian ialah perokok dan masing-masing subjek memiliki poket dalam $(>6 \mathrm{~mm})$ serta membutuhkan perawatan periodontal yang komprehensif. Pada lansia wanita yang telah mengalami menopause terdapat beberapa perubahan fisiologik di dalam tubuh berkaitan dengan perubahan kadar hormon, termasuk pada jaringan rongga mulut. ${ }^{23}$ Berkurangnya kadar estrogen pada lansia wanita dihubungkan dengan peningkatan resorbsi tulang alveolar, kehilangan perlekatan jaringan periodonsium, dan peningkatan keparahan penyakit periodontal. ${ }^{24}$

Hasil analisis menunjukkan pengetahuan kesehatan gigi dan mulut tidak memiliki hubungan bermakna dengan perilaku kesehatan gigi dan mulut. Hasil penelitian ini didukung oleh pernyataan Notoamodjo ${ }^{20}$ bahwa perilaku tidak hanya dipengaruhi oleh faktor pengetahuan tetapi terdapat faktor lain seperti fasilitas dan sarana serta faktor pendorong dari orang lain, seperti keluarga. Menurut Kotler, ketersediaan fasilitas jasa akan memengaruhi individu untuk meminta pelayanan jasa. Kelengkapan fasilitas kesehatan akan memengaruhi sikap dan perilaku individu. ${ }^{25}$ Lansia yang tinggal di Panti Jompo juga hidup jauh dari keluarga yang menyebabkan lansia kurang mendapat dorongan dari keluarga sehingga kurang termotivasi untuk menjaga kesehatan gigi dan mulutnya. ${ }^{26}$ Status sosial ekonomi turut memengaruhi sikap dan perilaku seseorang dalam upaya pemeliharaan kesehatan gigi dan mulut. Individu dengan tingkat ekonomi rendah akan lebih berkonsentrasi terhadap pemenuhan kebutuhan dasar yang menunjang kehidupannya. ${ }^{27}$

Hasil analisis yang telah dilakukan menunjukkan tingkat pengetahuan kesehatan gigi dan mulut memiliki pengaruh bermakna terhadap persepsi permasalahan gingiva. Hal ini selaras dengan penelitian Maida et $\mathrm{al}^{28}$ yang menyatakan bahwa semakin baik tingkat pengetahuan seseorang maka semakin rendah skor indeks gingiva, yang berarti terdapat hubungan bermakna. Pengetahuan sebagai faktor predisposisi perilaku memiliki pengaruh terhadap 
kesehatan gingiva, yang didukung oleh teori Green yaitu pengetahuan merupakan faktor predisposisi terbentuknya perilaku dan teori Bloom yang menyatakan status kesehatan individu dipengaruhi oleh empat faktor yaitu perilaku, lingkungan, pelayanan kesehatan, dan keturunan. ${ }^{28}$

Hasil analisis menunjukkan perilaku kesehatan gigi dan mulut memiliki pengaruh bermakna terhadap persepsi permasalahan gingiva. Hasil penelitian Erawati et al ${ }^{29}$ juga menyatakan bahwa terdapat pengaruh bermakna dari perilaku kesehatan gigi dan mulut terhadap terjadinya gingivitis. Perilaku kesehatan dipengaruhi oleh adanya faktor eksternal dan internal. Faktor eksternal atau stimulus yang berasal dari luar diri individu seperti faktor lingkungan baik fisik maupun non fisik dari segi sosial, budaya dan ekonomi. Faktor internal merupakan faktor yang muncul dari dalam diri individu dan menentukan bagaimana respon terhadap faktor eksternal seperti perhatian, pengamatan, motivasi, dan sugesti. ${ }^{28}$

Hasil analisis yang dilakukan menunjukkan tingkat pengetahuan dan perilaku kesehatan gigi dan mulut memiliki pengaruh bermakna terhadap persepsi permasalahan gingiva. Hal ini sesuai dengan penelitian yang dilakukan Astuti $^{6}$ yang menyatakan bahwa pengetahuan dan perilaku kesehatan gigi dan mulut secara bersama-sama berpengaruh positif terhadap status kesehatan periodontal. Perbedaan penelitian ini dengan penelitian yang dilakukan sebelumnya ialah dalam hal variabel terikat yang digunakan.

Pada individu yang sudah mulai memahami risiko penyakit dan keparahan yang akan timbul pada dirinya jika tidak berperilaku sehat, maka muncul kesadaran individu untuk melakukan tindakan pencegahan terhadap penyakit. Individu yang telah memiliki pengetahuan mengenai dampak buruk dan cara pencegahan penyakit gingivitis akan berupaya agar terhindar dari penyakit dengan menjaga kebersihan gigi dan mulut sehingga didapatkan gingiva yang sehat. ${ }^{28}$

Keterbatasan penelitian ini yaitu pengambilan data hanya dilakukan di Unit
Rehabilitasi Sosial Pucang Gading Semarang karena merupakan panti jompo satusatunya yang menampung lansia terlantar di Kota Semarang sehingga kurang dapat menggambarkan populasi lansia yang ada. Adanya pandemi Covid-19 juga menyebabkan pengisian kuesioner tidak dapat didampingi secara langsung dan tidak dapat dilakukan pemeriksaan intraoral untuk mengetahui permasalahan gingiva pada responden.

\section{SIMPULAN}

Pada lansia di Unit Rehabilitasi Sosial Pucang Gading Kota Semarang didapatkan pengaruh bermakna pengetahuan dan perilaku kesehatan gigi dan mulut terhadap persepsi permasalahan gingiva. Sebagian besar lansia memiliki tingkat pengetahuan kesehatan gigi dan mulut kategori buruk serta perilaku kesehatan gigi dan mulut kategori sedang dan buruk

Tidak terdapat hubungan bermakna antara pengetahuan dan perilaku kesehatan gigi dan mulut lansia. Persepsi permasalahan gingiva pada lansia paling banyak berada dalam kategori sedang. Permasalahan gingiva terbanyak ialah gusi bengkak

\section{Konflik Kepentingan}

Penulis menyatakan tidak terdapat konflik kepentingan pada studi ini.

\section{DAFTAR PUSTAKA}

1. Naftali AR, Ranimpi YY, Anwar MA. Kesehatan spiritual dan kesiapan lansia dalam menghadapi kematian. Bul Psikol. 2017;25(2):124-35.

Doi:10.22146/buletinpsikologi.28992

2. Wardhana SG, Baehaqi M, Amalina R. Pengaruh kehilangan gigi posterior terhadap kualitas hidup individu lanjut usia studi terhadap individu lanjut usia di Unit Rehabilitasi Sosial Pucang Gading Dan Panti Wredha Harapan Ibu Semarang. Odonto Dent J. 2015;2(1):40.

Doi:10.30659/odj.2.1.40-45

3. Badan Pusat Statistik Kota Semarang. Profil Lansia Kota Semarang 2018. Badan Pusat Statistik Kota Semarang. Published online 2018; p. 10.

4. BAPPEDA dan Badan Pusat Statistik Kota 
Semarang. Statistik Kesejahteraan Rakyat Kota Semarang 2014. 2015. Doi:10.1017/CBO9781107415324.004

5. Dinas Kesehatan Kota Semarang. Profil Kesehatan 2016. J Chromatogr B Biomed Sci Appl. 2016;662(2):181-90. doi:10.1016/0378-4347(94)00204-5

6. Astuti NR. Hubungan antara pengetahuan dan perilaku pemeliharaan kesehatan gigi dan mulut dengan status kesehatan periodontal pada lanjut usia (kajian di Panti Wreda Abiyoso). J Ilm dan Teknol Kedokt Gigi. 2018;14(2):33. Doi:10.32509/jitekgi.v14i2.638

7. Kiik SM, Sahar J, Permatasari H. Peningkatan kualitas hidup lanjut usia (lansia) di Kota Depok dengan latihan keseimbangan. J Keperawatan Indones. 2018; 21(2):109-16. Ddoi:10.7454/jki.v21i2.584

8. Wreksoatmodjo BR. Perbedaaan karakteristik lanjut usia yang tinggal di keluarga dengan yang tinggal dipanti di Jakarta Barat. Cermin Dunia Kedokt. 2013; 40(10):738-45.

9. Ghozali TR. Evaluasi pelayanan rehabilitasi sosial lanjut usia terlantar pada Unit Rehabilitasi Sosial Pucang Gading Semarang. Journal of Politic and Government Studies. 2014;3(1):231-50.

10. 1Nidyawati N, Wicaksono DA, Soewantoro JS. Gambaran tingkat pengetahuan dan kebersihan mulut pada masyarakat lanjut usia di Kelurahan Rurukan Kecamatan Tomohon Timur. Jurnal Biomedik. 2013;5(1):169-74. Doi:10.35790/jbm.5.1.2013.2640

11. Budiharto. Pengantar Ilmu Perilaku Kesehatan dan Pendidikan Kesehatan Gigi. Jakarta: EGC, 2010.

12. Rahayu C, Widiati S, Widyanti N. Hubungan antara pengetahuan, sikap, dan perilaku terhadap pemeliharaan kebersihan gigi dan mulut dengan status kesehatan periodontal pra lansia di Posbindu Kecamatan Indihiang Kota Tasikmalaya. Maj Kedokt Gigi Indones. 2014;21(1):27. Doi:10.22146/majkedgiind.8515

13. Mahendra NR, Krismariono A, Rubianto DM. Keparahan gingivitis pada pasien poli gigi Puskesmas Sawahan Surabaya Tahun 2016. Research Report Universitas Airrlangga. 2016;(January):15.

14. Badan Penelitian dan Pengembangan Kesehatan Kementerian Kesehatan RI. Riset
Kesehatan Dasar (RISKESDAS).; 2013.

15. Sarwono S. Individu dan Teori-Teori Psikologi. Jakarta: Balai Pustaka, 2002.

16. Notoatmodjo S. Faktor-faktor yang mempengaruhi pengetahuan. Jakarta: Rineka Cipta, 2010.

17. Purnamasari L. Perlindungan hak atas jaminan kesehatan lansia di panti wredha Kota Semarang (Thesis). Semarang: Unika Soegijapranata; 2019.

18. Dharmawati IGAA, Wirata IN. Hubungan tingkat pendidikan, umur, dan masa kerja dengan tingkat pengetahuan kesehatan gigi dan mulut pada guru penjaskes SD di Kecamatan Tampak Siring Gianyar. J Kesehat Gigi. 2016; 4(1):1-5.

19. Hurlock EB. Psikologi Perkembangan: Suatu Pendekatan Sepanjang Rentang Kehidupan. Ciracas: Penerbit Erlangga, 1998.

20. Notoatmodjo S. Perilaku Kesehatan dan Ilmu Perilaku. Jakarta: Rineka Cipta, 2007.

21. Hutauruk DP. Kebutuhan perawatan periodontal pada lansia di Kecamatan Medan Baru [Skripsi]. Medan: Universitas Sumatera Utara; 2017.

22. Chatzopoulos GS, Tsalikis L. Periodontal treatment needs and systemic diseases in an older population in Greece. J Clin Exp Dent. 2016;8(1):e32-e37. Doi: $10.4317 /$ jced.52763

23. Natarajan J. Review literature on distress during the menopausal transition and their impact on the quality of life of women: what is the evidence? IOSR J Nurs Heal Sci. 2013;2(4):01-10.

Doi:10.9790/1959-0240110

24. Alves RC, Félix SA, Rodriguez-Archilla A, Oliveira P, Brito J, Dos Santos JM. Relationship between menopause and periodontal disease: a cross-sectional study in a Portuguese population. Int $\mathbf{J}$ Clin Exp Med. 2015;8(7):11412-9.

25. Kiswaluyo. Pelayanan kesehatan gigi di puskesmas (Studi kasus di Puskesmas Sumbersari). JKG Unej. 2012;10(1):12-6.

26. Mujahidin A, Sampoerna G. Hubungan tindakan kesehatan gigi dan mulut pasien terhadap kepatuhan dalam menjalani perawatan berulang. Conserv Dent J. 2019;8(2):112. Doi:10.20473/cdj.v8i2.2018.112-117

27. Haryani W, Purwati DE, Satrianingsih S. Hubungan antara tingkat pendidikan 
dan status ekonomi dengan kepatuhan perawatan gigi tiruan lepasan. Maj Kedokt Gigi Indones. 2017;3(3):42. Doi:10.22146/majkedgiind.26806

28. Maida DC, Adhani R. Hubungan tingkat pengetahuan menyikat gigi dengan indeks gingiva siswa Madrasah Tsanawiyah. Dentino J Kedokt Gigi. 2017;
I(1):6-10.

29. Erawati S, Anastasia I, Nasution MSF. Pengaruh pengetahuan, sikap dan perilaku kesehatan gigi dan mulut terhadap terjadinya gingivitis pada wanita menopause di Perwiritan Al Hidayah Desa Limau Manis Tanjung Morawa. Prima J Oral Dent Sci. 2018;1(1):24-30. 